\title{
Removal of Toxicants from Leather Industrial Wastewater Using Sawdust Filter Media and Ferric Oxide Coagulant
}

\author{
MANJUSHREE CHOWDHURY*1, MD. ISRAIL HOSSAIN', AMAL KANTI DEB'1, \\ TAPAN KUMAR BISWAS ${ }^{2}$, FORHAD AHAMMED BIN AZAM ${ }^{1}$ and MD. DELWAR HOSSAIN ${ }^{1}$
}

${ }^{1}$ Institute of Leather Engineering and Technology, University of Dhaka, Dhaka-1209, Bangladesh.

${ }^{2}$ Department of Chemistry, University of Rajshahi, Rajshahi-6205, Bangladesh.

*Corresponding author E-mail: israil.rafi.du@gmail.com, manjushreechow@gmail.com

http://dx.doi.org/10.13005/ojc/350213

(Received: February 09, 2019; Accepted: March 31, 2019)

\begin{abstract}
The leather industrial wastewaters are a major source of water pollution among all industrial sector considering both quantity and composition. This research study was focused on the current chemical and physical parameters of tannery wastewater and treatment processes through sawdust filter media and ferric oxide $\left(\mathrm{Fe}_{2} \mathrm{O}_{3}\right)$ coagulant. The study found that tannery wastewater contained exceptionally high values of TDS, TSS, TS, $\mathrm{BOD}, \mathrm{COD}, \mathrm{SO}_{4}{ }^{2-}, \mathrm{Cl}-, \mathrm{Na}^{+}, \mathrm{Ca}^{++}$, chromium, lead, cadmium and arsenic and these parameters of the composite were exceeded the standard discharge limits which are considered as toxicants for the environment. The wastewaters were filtered by saw-dust filtration processes and then treated with different dosage of $\mathrm{Fe}_{2} \mathrm{O}_{3}$. The experiment elucidated that the filtration technique could minimize certain amount of toxicant load from the wastewater but not efficient enough to practise the technique alone using as wastewater treatment. The chemical interaction with $100 \mathrm{mg} / \mathrm{L}$ coagulant $\left(\mathrm{Fe}_{2} \mathrm{O}_{3}\right)$ dosage at $\mathrm{pH} \sim 9$ showed the best result of the major parameters. The study suggested that both combined physical (filtration) and chemical $\left(\mathrm{Fe}_{2} \mathrm{O}_{3}\right.$, coagulants) treatment processes could be fruitful to reduce the toxicants load from tannery wastewater.
\end{abstract}

Keywords: Tannery, Wastewater, Sawdust, Ferric oxide, Toxicant, Treatment.

\section{INTRODUCTION}

The leather is the second highest foreign currency earner sector in Bangladesh next to Ready Made Garments (RMG). The leather is used to making different type of products such as footwear, leather garments and leather goods etc. Among these products footwear itself consumed about $65 \%$ of the total leather. However the tanning industries are considered as the most polluted sector in Bangladesh because of high level of chemicals including salinity, alkalinity, organic and inorganic matters, dissolved, suspended solids, total kjeldahl nitrogen (TKN), specific pollutants and different heavy metals etc. ${ }^{1-3}$. In recent time, the leather industries were relocated from Hazaribagh to the leather industrial zone in saver an attempt to save the Buriganga, the lifeline to the capital Dhaka. There

This is an Open Access article licensed under a Creative Commons license: Attribution 4.0 International (CC- BY). Published by Oriental Scientific Publishing Company @ 2018 
are about 155 tanneries are allocated on 200 acres of land in the Savar Leather Industrial zone. They are consisting of two main tanning techniques such as chrome tanning and vegetable tanning.

In the present day, chromium salts (around $33 \%$ basic chromium sulphate) are extensively used as tanning substance. The hides and skins tanned with $\mathrm{Cr}$ salts have a better mechanical property, a remarkable dyeing propriety and hydrothermal property in comparison with hides and skins which is interacted with vegetable and other tanning materials. The leather takes up around $60 \%$ of applied chromium and the rest of metallic salts (40\%) are usually discharged into wastewaters during the tanning period which have serious environmental impact ${ }^{4}$. There are many techniques are available for tannery wastewater treatment to remove toxicant or pollution load but adsorption is one of the promising processes for wastewater treatment. Recently, low cost materials, including rice-husk, maple sawdust, soya cake, coal ash, peat and bone char, have been investigated as adsorbents for wastewater treatment ${ }^{5}$. Au et al.,(2018) ${ }^{6}$ reported that saw dust was used to remove chromium from tannery effluents. Many researchers studied that in many cases after saw dust filter a chemical pretreatment was needed to activate the sorption sites ${ }^{7}$. Batzias et al.,(2013) ${ }^{8}$ reported that clay minerals are natural substances used in wastewater treatment for metal ions $(\mathrm{Cd}$ and $\mathrm{Pb})$ removal.

The present experiment was to evaluate the degradation of toxicants from leather industrial wastewater by combined physical and chemical treatments. Iron salt was used as coagulant. The aim of this experiment was to determine the comparative toxicity of tannery wastewater before and after interaction. At first, pickling and chrome tanning wastewaters were characterized and then compared to the standard permissible limits. Therefore, in this experiment; a step has been made to analyze the effectiveness of saw dust adsorption filtration and coagulant $\mathrm{Fe}_{2} \mathrm{O}_{3}$ to interfere the tannery wastewater of Bangladesh. There are other treatment techniques found around the world, yet this experiment, considering the socioeconomic aspect of Bangladesh, cheap cost coagulant has been selected for the treatment of industrial tannery wastewater.

\section{MATERIALS AND METHODS}

\section{Study Location}

The experimental area is located at the tannery industrial estate at Savar on the bank of the river Dhaleshwari and the South Western part of Dhaka city (Fig. 1), Bangladesh. The wastewater was collected from Marsons Tannery Ltd. and Al-Madina Tannery in the tannery village.

The present study was conducted during the year November 2017- June 2018 and the tannery wastewaters were collected at February 2018 located in the sampling area. These discharged wastewaters were treated with sawdust filter and chemical processes.

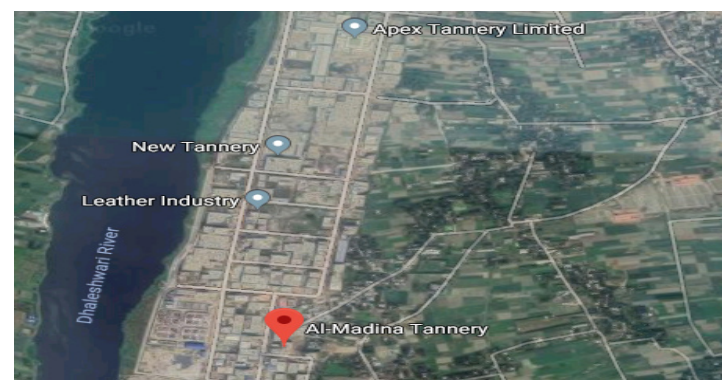

Fig. 1. Sampling location of the leather industrial zone Savar, Dhaka Bangladesh

\section{Treatment process and Characteristics of tannery wastewater}

The collected wastewaters were performed both physical and chemical treatment. Firstly in physical treatment, $2 \mathrm{~L}$ of tannery wastewater was taken in a sample beaker and allowed to settle for 24 hours. After settling, $1 \mathrm{~L}$ supernatant was transfer into another beaker and added $50 \mathrm{mg} / \mathrm{L}$ lime to minimize the solubility of cations in wastewater and approved to settle down for a day. Total suspended solids were allowed to settle again by flock formation. After completion of settling, the supernatant clear liquids were enforced through saw dust filtration media.

In chemical treatment, $\mathrm{Fe}_{2} \mathrm{O}_{3}$ is considered as coagulant and a definite dose of coagulants, $\mathrm{Fe}_{2} \mathrm{O}_{3}$ $(50,70,100,150,200,250,400$ and $500 \mathrm{mg} / \mathrm{L})$ were accumulated to the filtered tannery wastewaters, stirred evenly for 20 minutes and then approved to settle down for 12-72 hours. Then the liquids were collected and analyzed for different physical and chemical parameters every $2 \mathrm{~h}$ during the process of 
treatment and finally the optimization of coagulation time was studied. The experiment was conducted using coagulant namely $\mathrm{Fe}_{2} \mathrm{O}_{3}$ which contributes $\mathrm{Fe}^{3+}$ ions in aqueous solution. The hydrolysis of $\mathrm{Fe}^{3+}$ (in aqueous solution) was illustrated and is written as follows. ${ }^{9-10}$

$\mathrm{Fe}^{3+}+\mathrm{y} \mathrm{H}_{2} \mathrm{O} \longrightarrow \mathrm{Fe}(\mathrm{OH}) \mathrm{y}^{(3-\mathrm{y})+}+\mathrm{yH}^{+}$(1)

$\mathrm{Fe}^{3+} \rightarrow \mathrm{Fe}(\mathrm{OH})^{2+} \rightarrow \mathrm{Fe}(\mathrm{OH})^{2+} \rightarrow \mathrm{Fe}(\mathrm{OH})_{3} \rightarrow \mathrm{Fe}^{2}(\mathrm{OH})_{2}{ }^{4+} \rightarrow$

$\mathrm{Fe}_{3}(\mathrm{OH})_{4}^{5+} \rightarrow \mathrm{Fe}(\mathrm{OH})_{4}^{-}$

The hydrolysis products Fe (III) may adsorb or chemically interact with suspended or dissolved components in the tannery effluents to form complex ions ${ }^{9}$. Ferric oxide $\left(\mathrm{Fe}_{2} \mathrm{O}_{3}\right)$, was typically added during wastewater treatment and readily hydrolyses to form an amorphous ferri hydrite, $\mathrm{Fe}(\mathrm{OH})_{3}$ as stated by Amuda et al., (2006) [11], which is given below.

$\mathrm{Fe}_{2} \mathrm{O}_{3}+6 \mathrm{H}_{2} \mathrm{O} \rightarrow 2 \mathrm{Fe}(\mathrm{OH})_{3 \downarrow}+2 \mathrm{H}_{3} \mathrm{O}^{+}$

The optimizations of coagulant $\mathrm{Fe}_{2} \mathrm{O}_{3}$ doses and $\mathrm{pH}$ were determined. The $\mathrm{pH}$ of the sample was adjusted with $1.0 \mathrm{M} \mathrm{NaOH}$ or $1.0 \mathrm{M} \mathrm{HCl}$. A schematic flow diagram of the wastewater treatment process is shown in Figure 2.

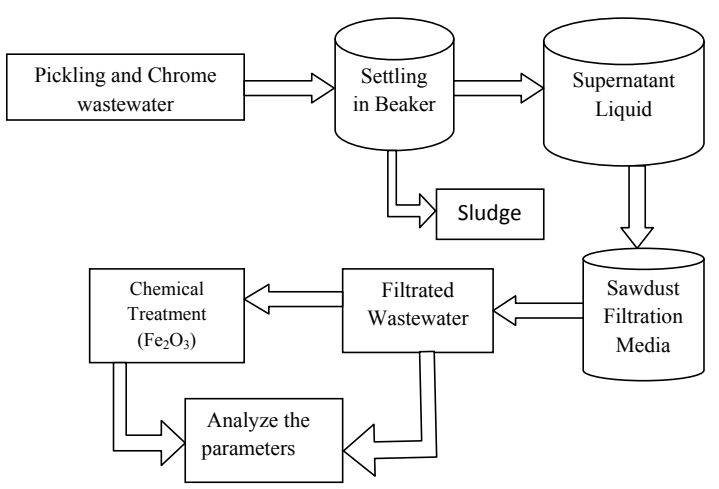

Fig. 2. Flow chart of physical and chemical treatment process of tannery wastewater

All collected samples were analyzed for considering some major physical and chemical parameters. The physical and chemical parameters like $\mathrm{pH}$, electrical conductivity (EC), TSS, and TDS, $\mathrm{BOD}_{5}$, COD of untreated, filtered and chemically treated wastewaters were measured. Colors were measured using Pt-Co color measurement unit. EC and $\mathrm{pH}$ values were found using digital $\mathrm{pH}$ meter (Model KP-5z, Japan) and a digital conductivity meter (Model Hanna 9033, Singapore). TDS, TSS and TS were determined gravimetrically (APHA 1998). COD value was measured using titrimetric method, $\left(75 \mathrm{~mL}\right.$ of $\mathrm{H}_{2} \mathrm{SO}_{4}$ (Conc.) was added to $25 \mathrm{~mL}$ of $0.25 \mathrm{~N} \mathrm{~K}_{2} \mathrm{Cr}_{2} \mathrm{O}_{7}$ solutions then reflux it for two hours. The excess dichromate was then titrated with $0.25 \mathrm{~N}$ $\left(\mathrm{NH}_{4}\right)_{2} \mathrm{Fe}\left(\mathrm{SO}_{4}\right)_{2} \cdot 6 \mathrm{H}_{2} \mathrm{O}$ solution using phenapthaline $\mathrm{FeSO}_{4}$ indicator). $\mathrm{BOD}_{5}$ was determined by 5 day BOD test method using oxitop machine. $\mathrm{SO}_{4}{ }^{2-}$ and $\mathrm{Cl}$ ions were determined as per standard of APHA (2005). Concentrations of heavy metal ions ( $\mathrm{Cr}, \mathrm{Cd}$, $\mathrm{Pb}$ and $\mathrm{As}$ ) in wastewaters were estimated using AAS (Shimadzu Model AA-6800). Untreated wastewaters were used as control. Percentage of removal efficiency was calculated as follows:

Removal efficiency $(\%)=\frac{\mathrm{C} 0-\mathrm{C} 1}{\mathrm{C} 0} \times 100$

Where, $\mathrm{C}_{0}$ was the concentration of control wastewaters, and $\mathrm{C}_{1}$ was the concentration of treated wastewaters.

\section{RESULTS AND DISCUSSIONS}

The physical and chemical characteristics of industrial tannery wastewater filtered with sawdust filtration media and $\mathrm{Fe}_{2} \mathrm{O}_{3}$ coagulant are given Tables 1 and 2.

Table 1: The characteristics of untreated and filtered industrial tannery wastewater and compared with standard

Variables Untreated Saw dust filtered Standards wastewater wastewater permissible limits (ISI-2000/ISWBDS)

\begin{tabular}{lccc}
\hline Appearance Yellowish- brown & Black & - \\
Color units & $(1772 \pm 2.17)$ & $(1455 \pm 4.49)$ & 15 \\
(Pt-Co) & & & \\
Odor & Disagreeable & Slightly -smell & Smell less \\
pH & $7.6 \pm 0.13$ & $8.2 \pm 0.02$ & $6-9$ \\
EC $(\mathrm{mS} / \mathrm{cm})$ & $18.71 \pm 0.67$ & $19.76 \pm 1.39$ & 0.288 \\
TSS $(\mathrm{mg} / \mathrm{L})$ & $6778 \pm 37.45$ & $5387 \pm 50.23$ & 100 \\
TDS $(\mathrm{mg} / \mathrm{L})$ & $14020 \pm 1.09$ & $16028 \pm 60.88$ & 2100 \\
TS $(\mathrm{mg} / \mathrm{L})$ & $20816 \pm 54.87$ & $21425 \pm 49.83$ & 2200 \\
BOD5 (mg/L) & $935 \pm 15.61$ & $1495 \pm 12.04$ & $30 / 250$ \\
COD $(\mathrm{mg} / \mathrm{L})$ & $3988 \pm 29.89$ & $6789 \pm 31.01$ & $250 / 400$ \\
SO42- $(\mathrm{mg} / \mathrm{L})$ & $4012 \pm 14.42$ & $3517 \pm 13.12$ & 1000 \\
Cl- $(\mathrm{mg} / \mathrm{L})$ & $5017 \pm 12.84$ & $1341 \pm 7.25$ & \\
\hline
\end{tabular}


Table 2: The characteristics of $\mathrm{Fe}_{2} \mathrm{O}_{3}$ treated industrial tannery wastewater

\begin{tabular}{|c|c|c|c|c|c|c|c|c|}
\hline \multirow[t]{2}{*}{ Variables } & & \multicolumn{7}{|c|}{$\mathrm{Fe}_{2} \mathrm{O}_{3}$ Coagulant dose (mg/L) } \\
\hline & 50 & 70 & 100 & 150 & 200 & 250 & 400 & 500 \\
\hline $\begin{array}{l}\text { Appearance } \\
\text { Color units (Pt-Co) }\end{array}$ & $\begin{array}{c}\text { DW } \\
(360 \pm)\end{array}$ & $\begin{array}{l}\text { Clear } \\
(280 \pm)\end{array}$ & $\begin{array}{l}\text { Clear } \\
(5 \pm)\end{array}$ & $\begin{array}{l}\text { Clear } \\
(25 \pm)\end{array}$ & $\begin{array}{l}\text { Clear } \\
(80 \pm)\end{array}$ & $\begin{array}{l}\text { Clear } \\
(120 \pm)\end{array}$ & $\begin{array}{c}\text { LB } \\
(400 \pm)\end{array}$ & $\begin{array}{c}\mathrm{Br} \\
(530 \pm)\end{array}$ \\
\hline Odor & AGS & AGS & AGS & AGS & AGS & AGS & AGS & SS \\
\hline $\mathrm{pH}$ & $10 \pm 0.5$ & $9.6 \pm 0.56$ & $9 \pm 0.2$ & $8.5 \pm 0.25$ & $8 \pm 0.26$ & $7.5 \pm 0.24$ & $6 \pm 0.25$ & $5 \pm 0.2$ \\
\hline $\mathrm{EC}(\mathrm{mS} / \mathrm{cm})$ & $6 \pm 0.12$ & $5.6 \pm 0.21$ & $1.5 \pm 0.5$ & $2.5 \pm 0.4$ & $4.65 \pm 1.0$ & $5.6 \pm 0.35$ & $6.8 \pm 0.5$ & $8.8 \pm 0.5$ \\
\hline TSS (mg/L) & $400 \pm 2$ & $200 \pm 1$ & $0 \pm 1.5$ & $100 \pm 2.5$ & $200 \pm 0.2$ & $600 \pm 2.2$ & $1000 \pm 1.2$ & $2000 \pm 5$ \\
\hline TDS(mg/L) & $5520 \pm .06$ & $4505 \pm 0.98$ & $3062 \pm 2.5$ & $3260 \pm 2.5$ & $4075 \pm 2.6$ & $4420 \pm 2.7$ & $5320 \pm 3.5$ & $6280 \pm 5.64$ \\
\hline TS (mg/L) & $5920 \pm 2.3$ & $4705 \pm 0.69$ & $3062 \pm 2.5$ & $3360 \pm 0.95$ & $4275 \pm 1.5$ & $5120 \pm 1.6$ & $6320 \pm 1.7$ & $8280 \pm 1.56$ \\
\hline $\mathrm{BOD}_{5}(\mathrm{mg} / \mathrm{L})$ & $730 \pm 1.23$ & $540 \pm 2.4$ & $200 \pm 2.6$ & $450 \pm 2.8$ & $500 \pm 2.5$ & $625 \pm 2.13$ & $700 \pm 2.6$ & $750 \pm 1.5$ \\
\hline $\mathrm{COD}(\mathrm{mg} / \mathrm{L})$ & $1230 \pm 2.3$ & $880 \pm 2.1$ & $300 \pm 1.3$ & $400 \pm 1.3$ & $850 \pm 4.0$ & $1050 \pm 1.6$ & $1680 \pm 0.07$ & $2020 \pm 0.05$ \\
\hline $\mathrm{SO}_{4}{ }^{2-}(\mathrm{mg} / \mathrm{L})$ & $1550 \pm 1.5$ & $1050 \pm 1.6$ & $600 \pm 1.6$ & $750 \pm 1.4$ & $1060 \pm .09$ & $1530 \pm 1.0$ & $1850 \pm 1.03$ & $2350 \pm 1.5$ \\
\hline Cl--(mg/L) & $1040 \pm 1.8$ & $850 \pm 0.09$ & $480 \pm 1$ & $580 \pm 1.5$ & $880 \pm 1.63$ & $1070 \pm 4$ & $1250 \pm 2$ & $2050 \pm 1.3$ \\
\hline
\end{tabular}

N.B.: DW: Dull- white color, AGS: Agreeable smell, LB: Light brownish, Br: Brownish and SS: Slightly smell

\section{Color, appearance and odor}

The average color and appearance of untreated industrial tannery wastewater were determined to be $1772 \pm 2.17 \mathrm{Pt}$-Co units and yellowish brown color respectively. The results indicated that the industrial tannery wastewater contained highly color compounds which are 118 times higher than standard value (15 Pt-Co units). The actual color of the wastewater (1772 $\pm 2.17 \mathrm{Pt}-\mathrm{Co}$ units) was decreased to $1455 \pm 4.49 \mathrm{Pt}$-Co units and appearance was found black due to filtration with sawdust filter media (Table 1). The odor was checked very bad smell from the untreated wastewater but unobjectionable odor was observed in the filtered wastewater. Similar review was found by Manu et al.,2011 12 .

The color of $100 \mathrm{mg} / \mathrm{L} \mathrm{Fe}_{2} \mathrm{O}_{3}$ treated wastewater was checked $5 \pm(\mathrm{Pt}-\mathrm{Co})$ unit which was found within standard limits. Evidently, clean water was found after completion of treatment with various doses (70-250) $\mathrm{mg} / \mathrm{L}$ of $\mathrm{Fe}_{2} \mathrm{O}_{3}$. When the coagulant $\left(\mathrm{Fe}_{2} \mathrm{O}_{3}\right)$ doses increased above $250 \mathrm{mg} / \mathrm{L}$, then the effluents' color turned clear to brown color appear (Table 2). The research results determined that $100 \mathrm{mg} / \mathrm{L}$ of $\mathrm{Fe}_{2} \mathrm{O}_{3}$ dose was the most practical for the removal of color. The results indicated that the color removal capacity was found better compared to the previous reports. Color results from treated industrial wastewater were found significantly different from the untreated wastewater. The odor was found very bad smell in untreated wastewater but very preferable odor was found after treatment with various doses of $\mathrm{Fe}_{2} \mathrm{O}_{3}$.

\section{$\mathrm{pH}$ and EC}

The results indicated that the mean values of $\mathrm{pH}$, the industrial untreated and treated wastewater were $7.6 \pm 1.3$ and $8.2 \pm 0.02$ respectively (Table 1 ). After completion of filtration, the wastewaters were treated with various doses $(50-500 \mathrm{mg} / \mathrm{L})$ of $\mathrm{Fe}_{2} \mathrm{O}_{3}$. The experimental results executed that the $\mathrm{pH}$ of treated wastewater were decreased with $\mathrm{Fe}_{2} \mathrm{O}_{3}$ doses increasing (shown in Table 2). Similar finding was reported by Chowdhury et al.,(2013)4; $\mathrm{pH}$ is vital parameter since the coagulation happens within a definite $\mathrm{pH}$ range for each coagulant.

The EC of indusstrial untreated tannery wastewater was executed $18.71 \pm 0.13 \mathrm{mS} / \mathrm{cm}$ which was higher than standard limit (Table 1). Results explained that EC of industrial untreated wastewater generally contained around $20 \mathrm{mS} / \mathrm{cm}$; Madal et al.,(2010) ${ }^{13}$ supporting the findings of this experiment. The results illustrated that $\mathrm{EC}$ of $\mathrm{Fe}_{2} \mathrm{O}_{3}$ treated wastewater was decreased sharply with $\mathrm{Fe}_{2} \mathrm{O}_{3}$ doses increasing until reached at the lowest EC value around 1.5 and then it gradually increased with concentrations of $\mathrm{Fe}_{2} \mathrm{O}_{3}$. The lowest value of $\mathrm{EC}$ was observed in $100 \mathrm{mg} / \mathrm{L} \mathrm{Fe}_{2} \mathrm{O}_{3}$ treated effluents indicating the efficiency of the coagulant dose (Fig. 3). These experimental results also found relatively better removal capacities (92\%) in removing the parameters at a dose of $100 \mathrm{mg} / \mathrm{L}$ $\mathrm{Fe}_{2} \mathrm{O}_{3}$ and $\mathrm{pH} 9$. 


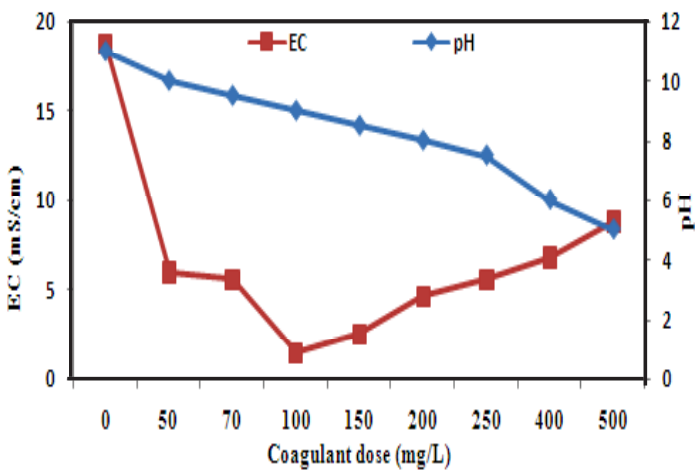

Fig. 3. Effect of coagulant $\left(\mathrm{Fe}_{2} \mathrm{O}_{3}\right)$ doses on $\mathrm{EC}$ and pH

\section{TSS, TDS and TS}

The mean values of TSS, TDS and TS of industrial untreated tannery wastewater were $6778 \pm 37.45,14020 \pm 1.09$ and $20816 \pm 54.87 \mathrm{mg} / \mathrm{L}$ accordingly, which were much high compared to the standard limits. After filtration with sawdust filter media, the values of TSS, TDS and TS were still very high (Table1). The results showed that in the beginning TSS, TDS and TS decreased with increasing $\mathrm{Fe}_{2} \mathrm{O}_{3}$ doses until they reached at a certain lowest value and then increased with $\mathrm{Fe}_{2} \mathrm{O}_{3}$ (Table 2). The results also revealed that $100 \mathrm{mg} / \mathrm{L}$ $\mathrm{Fe}_{2} \mathrm{O}_{3}$ treated wastewater showed the lowest TSS concentration which was well below the prescribed standard. $100 \mathrm{mg} / \mathrm{L}$ of $\mathrm{Fe}_{2} \mathrm{O}_{3}$ treated wastewater showed the lowest TDS and TS values which were found to be the same i.e., $3062 \mathrm{mg} / \mathrm{L}$, (Fig. 4). The lowest values of TSS, TDS and TS were found to be in $100 \mathrm{mg} / \mathrm{L}$ of $\mathrm{Fe}_{2} \mathrm{O}_{3}$ treated wastewater. The results revealed that the concentration of TSS was almost "zero" (0) mg/L and the removal capacity was $100 \%$ at a coagulant $\left(\mathrm{Fe}_{2} \mathrm{O}_{3}\right)$ dose of $100 \mathrm{mg} / \mathrm{L}$ indication of the compatibility of the coagulant dose.

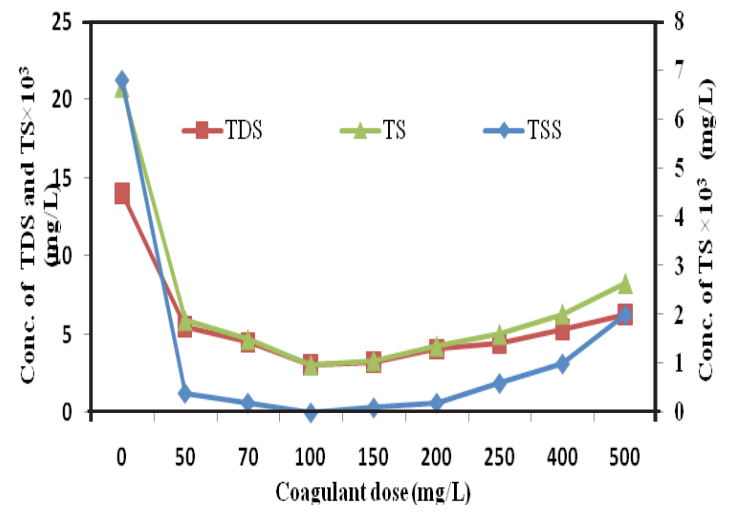

Fig. 4: Effect of coagulant $\left(\mathrm{Fe}_{2} \mathrm{O}_{3}\right)$ doses on TSS, TDS and TS

\section{$\mathrm{BOD}_{5}$ and COD}

The mean values of $\mathrm{BOD}_{5}$ and $\mathrm{COD}$ of industrial tannery wastewater were 935 and 3988 $\mathrm{mg} / \mathrm{L}$, successively. The experimental results described that $\mathrm{BOD}_{5}$ and $\mathrm{COD}$ values were found to be higher than those of standards for the ISW-BDS and ISI. The mean values of parameters $\mathrm{BOD}_{5}$ and $\mathrm{COD}$ for the filtered wastewater are shown in Table 1. The results revealed that the only filtration process was not good enough for $\mathrm{BOD}_{5}$ and $\mathrm{COD}$ removal suggesting the need for further treatment using suitable chemicals.

The results also illustrated that in the beginning $\mathrm{BOD}_{5}$, $\mathrm{COD}$ values decreased with increasing $\mathrm{Fe}_{2} \mathrm{O}_{3}$ doses till they reached at certain the lowest values and then increased with $\mathrm{Fe}_{2} \mathrm{O}_{3}$ doses (Table 2). The lowest values of $\mathrm{BOD}_{5}$ $(200 \mathrm{mg} / \mathrm{L})$ and $\operatorname{COD}(300 \mathrm{mg} / \mathrm{L})$ were found in 100 $\mathrm{mg} / \mathrm{L} \mathrm{Fe}{ }_{2} \mathrm{O}_{3}$ treated effluents which were found to be within the standard limits for ISW-BDS.

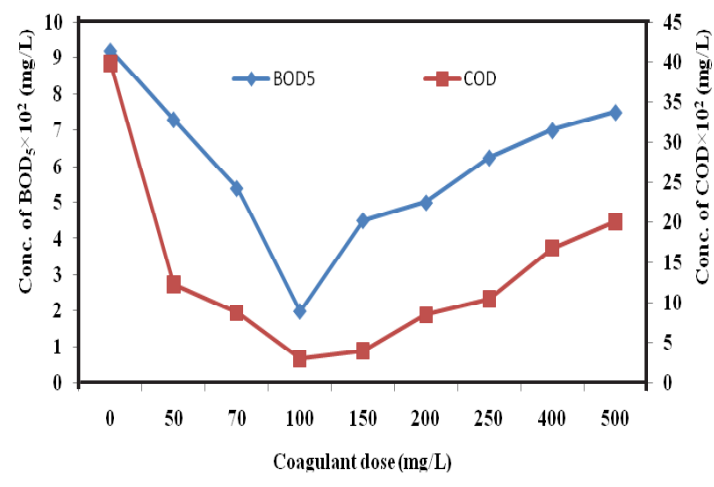

Fig. 5. Effect of coagulant $\left(\mathrm{Fe}_{2} \mathrm{O}_{3}\right)$ doses on BOD5 and COD

\section{Sulfate $\left(\mathrm{SO}_{4}{ }^{2-}\right)$ and chloride $(\mathrm{Cl})$}

The mean values of $\mathrm{SO}_{4}{ }^{2-}$ and $\mathrm{Cl}$ - in $\mathrm{Fe}_{2} \mathrm{O}_{3}$ treated wastewaters are shown in Table 2 which was found in relation between $\mathrm{Fe}_{2} \mathrm{O}_{3}$ doses and contained values of $\mathrm{SO}_{4}{ }^{2-}$ and $\mathrm{Cl}^{-}$. The analyze results revealed that $100 \mathrm{mg} / \mathrm{L} \mathrm{Fe}_{2} \mathrm{O}_{3}$ treated effluent showed the highest removal efficiency for $\mathrm{Cl}^{-}$and $\mathrm{SO}_{4}{ }^{2-}$ and the values were found to be 480 and 600 $\mathrm{mg} / \mathrm{L}$, successively. The results indicated that the maximum $\mathrm{SO}_{4}^{2-}$ and $\mathrm{Cl}^{-}$removal capacity executed were 85 and $90 \%$, respectively and the value was below the standards limits. The study also observed that the concentration of $\mathrm{SO}_{4}{ }^{2-}$ in the untreated wastewater was $4012 \mathrm{mg} / \mathrm{L}$ and filtered wastewater was $3517 \mathrm{mg} / \mathrm{L}$ Table 1). 


\section{Concentration of Metal alcalins/ions}

The average concentration of metals ions of the filtered and $\mathrm{Fe}_{2} \mathrm{O}_{3}$ treated wastewater are shown in Tables 3 and 4.

The highest metal ions concentrations in the raw wastewater were found for $\mathrm{Na}$ and $\mathrm{Ca}$ and their mean values were $3862 \pm 38.02$, and $774 \pm 4.20$

Table 3: Reduction of dissolved cations from industrial tannery wastewater by filtration and compared with standard limits

\begin{tabular}{lccc}
\hline Variables & $\begin{array}{c}\text { Untreated } \\
\text { wastewater }\end{array}$ & $\begin{array}{c}\text { Saw dust filtered } \\
\text { wastewater }\end{array}$ & $\begin{array}{c}\text { Standards limits } \\
\text { (ISI-2000)/ISWBDS }\end{array}$ \\
\hline $\mathrm{Na} \mathrm{(mg/L)}$ & $3862 \pm 38.02$ & $3012 \pm 18.83$ & - \\
$\mathrm{Ca}(\mathrm{mg} / \mathrm{L})$ & $774 \pm 4.20$ & $726 \pm 3.90$ & 200 \\
$\mathrm{Cr}(\mathrm{mg} / \mathrm{L})$ & $9.89 \pm 0.68$ & $6.72 \pm 0.21$ & $0.1 / 2$ \\
$\mathrm{~Pb}(\mathrm{mg} / \mathrm{L})$ & $5.28 \pm 0.17$ & $5.12 \pm 0.17$ & 0.2 \\
$\mathrm{Cd}(\mathrm{mg} / \mathrm{L})$ & $3.47 \pm 0.048$ & $3.32 \pm 0.19$ & 0.1 \\
$\mathrm{As}(\mathrm{mg} / \mathrm{L})$ & $1.40 \pm 0.14$ & $1.25 \pm 0.21$ & 0.1 \\
\hline
\end{tabular}

$\mathrm{mg} / \mathrm{L}$, accordingly (Table 3). The research findings of the filtrated wastewater indicated that all the filtration processes were not suitable to remove heavy metal ions and $\mathrm{Na}, \mathrm{Ca}$ alcalins.

The average concentration of $\mathrm{Na}, \mathrm{Ca}, \mathrm{Cr}$, $\mathrm{Cd}$, As and $\mathrm{Pb}$ ions in $\mathrm{Fe}_{2} \mathrm{O}_{3}(50-500 \mathrm{mg} / \mathrm{L})$ treated effluents are illustrated in Table 4 . The results observed that $100 \mathrm{mg} / \mathrm{L} \mathrm{Fe}_{2} \mathrm{O}_{3}$ treated wastewater contained the lowest $\mathrm{Na}$ value which was found to be $460 \mathrm{mg} / \mathrm{L}$. The value was still far above the standards limits, suggesting the need for further treatment. The analysis results also observed that $100 \mathrm{mg} / \mathrm{L} \mathrm{Fe}_{2} \mathrm{O}_{3}$ treated effluents showed the lowest concentration of major metal ions and the values were: $140,0.1,0.2,0.1$ and $0.1 \mathrm{mg} / \mathrm{L}$ for $\mathrm{Ca}, \mathrm{Cr}$, $\mathrm{Pb}, \mathrm{Cd}$ and As respectively (Table 4). The research revealed that $100 \mathrm{mg} / \mathrm{L} \mathrm{Fe}_{2} \mathrm{O}_{3}$ dose found the best removal efficiency for all of major metal ions.

Table 4: Reduction of cations of filtrated tannery wastewater by Fe2O3 treatment

\begin{tabular}{lcccccccc}
\hline Variables & \multicolumn{7}{c}{ Fe2O3 Coagulant dose $(\mathrm{mg} / \mathrm{L})$} \\
& 50 & 70 & 100 & 150 & 200 & 250 & 400 \\
\hline $\mathrm{Na}(\mathrm{mg} / \mathrm{L})$ & $1830 \pm 2.4$ & $1020 \pm 1.3$ & $460 \pm 1.63$ & $860 \pm 2.5$ & $950 \pm 1.8$ & $1020 \pm 1.45$ & $1300 \pm 1.56$ & $1540 \pm 1.5$ \\
$\mathrm{Ca}((\mathrm{mg} / \mathrm{L})$ & $280 \pm 2.7$ & $200 \pm 1.8$ & $140 \pm 1.8$ & $240 \pm 1.02$ & $360 \pm 1.4$ & $450 \pm 1.2$ & $650 \pm 2.06$ & $750 \pm 0.41$ \\
$\mathrm{Cr}(\mathrm{mg} / \mathrm{L})$ & $5.2 \pm 0.07$ & $3.5 \pm 0.5$ & $0.1 \pm 0.05$ & $0.65 \pm 0.06$ & $0.95 \pm 0.06$ & $2.5 \pm 1.3$ & $3.5 \pm .52$ & $4.5 \pm 0.08$ \\
$\mathrm{~Pb}(\mathrm{mg} / \mathrm{L})$ & $2.5 \pm 0.05$ & $0.67 \pm 0.6$ & $0.2 \pm 0.03$ & $0.45 \pm 0.09$ & $0.70 \pm 0.04$ & $1.5 \pm 0.5$ & $2.5 \pm 0.06$ & $3.5 \pm 0.21$ \\
$\mathrm{Cd}(\mathrm{mg} / \mathrm{L})$ & $1.75 \pm 0.06$ & $0.5 \pm 0.4$ & $0.1 \pm 0.05$ & $0.65 \pm 0.06$ & $0.95 \pm 0.06$ & $1.85 \pm 0.07$ & $2.9 \pm 0.08$ & $3.2 \pm 0.05$ \\
$\mathrm{As}(\mathrm{mg} / \mathrm{L})$ & $0.65 \pm 0.04$ & $0.35 \pm 0.05$ & $0.1 \pm 0.05$ & $0.2 \pm 0.04$ & $0.3 \pm 0.02$ & $0.5 \pm 0.05$ & $0.65 \pm 0.09$ & $0.95 \pm 0.06$ \\
\hline
\end{tabular}

\section{Influencing parameters on treatment processes} Effect of coagulant dose

Various amount of $\mathrm{Fe}_{2} \mathrm{O}_{3}(50-500 \mathrm{mg} / \mathrm{L})$ doses were applied to observe the optimum coagulant dose at definite $\mathrm{pH} 9$ and room temperature $\left(25 \pm 1^{\circ} \mathrm{C}\right)$ for the treatment of wastewater. The effect of coagulant $\left(\mathrm{Fe}_{2} \mathrm{O}_{3}\right)$ dose on the removal capacity of various indicators (EC, TSS COD, $\mathrm{SO}_{4}^{2-}, \mathrm{Cl}-\mathrm{Cr}$, As and $\mathrm{Cd}$ ) are illustrated in Fig. 6. The figure explained that the removal efficiency of parameters initially increased with dose until it reached peak point and then it decreased. The maximum removal efficiencies for various factors were achieved $92 \%$ (EC), 92\% (COD), 100\% (TSS), 85\% ( $\mathrm{SO}_{4}{ }^{2-}$ ), $99 \%$ (Cr), 93\% (As), and $97 \%(\mathrm{Cd})$. The findings of this experiment executed that the coagulant was not adequate to form flocks or to bind the colloid particles to form bridging. At higher doses (more than $100 \mathrm{mg} / \mathrm{L}$ ) of the coagulant, the colloid particles become suspended due to electrostatics repulsion between colloid particles and coagulant and in low flock appearance. The present experiment observed that $100 \mathrm{mg} / \mathrm{L}$ coagulant $\left(\mathrm{Fe}_{2} \mathrm{O}_{3}\right)$ dose indicated maximum removal capacity. A high coagulant dose in effluent treatment process increase operational costs and produce a large amount of sludge. In this study, the coagulant amount used was relatively smaller than used in the previous studies ${ }^{14}$.

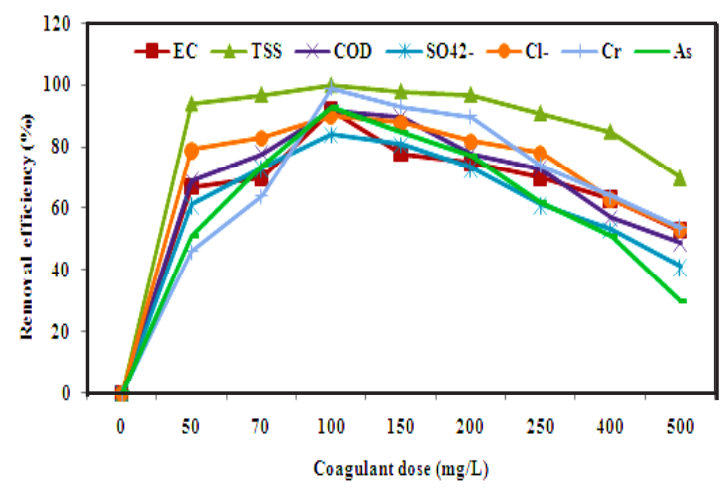

Fig. 6. Effect of coagulant $\left(\mathrm{Fe}_{2} \mathrm{O}_{3}\right)$ doses on the removal capacity of various indictors ( $\mathrm{EC}, \mathrm{TSS}, \mathrm{COD}, \mathrm{Cl}^{-}, \mathrm{SO}_{4}{ }^{2-}$, As and $\mathrm{Cr}$ ) 


\section{Effect of $\mathrm{pH}$}

The study carried out in the $\mathrm{pH}$ range from 4 to 11.5 to determine the optimum $\mathrm{pH}$ value at a definite coagulant dose $\left(100 \mathrm{mg} / \mathrm{L} \mathrm{Fe}_{2} \mathrm{O}_{3}\right)$ and room temperature $\left(25 \pm 1^{\circ} \mathrm{C}\right)$. The effect of $\mathrm{pH}$ on the removal capacity (\%) is given in Fig. 7. The maximum capacities for various factors were found to be at $\mathrm{pH} 9$ and they gradually decreased on both sides of $\mathrm{pH}$. Fig. 7: Effect of $\mathrm{pH}$ on TSS, COD, $\mathrm{SO}_{4}{ }^{2-}, \mathrm{Cl}-, \mathrm{Cr}, \mathrm{As}$, $\mathrm{Cd}$ and $\mathrm{Pb}$ for coagulant $\mathrm{Fe}_{2} \mathrm{O}_{3}$.

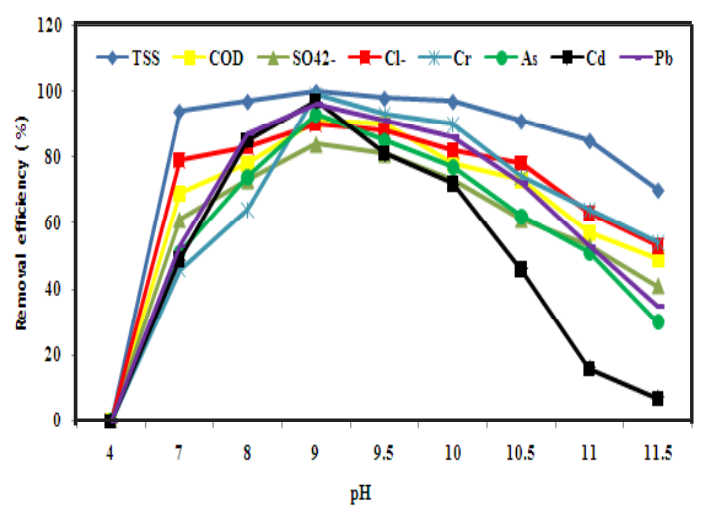

Fig. 7. Effect of $\mathrm{pH}$ on TSS, COD, $\mathrm{SO}_{4}{ }^{2-}, \mathrm{Cl}-\mathrm{Cr}, \mathrm{As}, \mathrm{Cd}$ and $\mathrm{Pb}$ for coagulant $\mathrm{Fe}_{2} \mathrm{O}_{3}$

The results illustrated that the highest removal capacities were 100, 92, 85, 90, 99 and 92 $\%$ for TSS, COD, $\mathrm{SO}_{4}{ }^{2-}, \mathrm{Cl}-, \mathrm{Cr}$ and As respectively. When a coagulant such as iron salt is added to $\mathrm{H}_{2} \mathrm{O}$, a series of soluble hydrolysis species are to be formed. These hydrolysis species have positive or negative charges considering on the $\mathrm{pH}$ of water. At low $\mathrm{pH}(<6)$ they are positively charged and at high $\mathrm{pH}$ they are negatively charged.

\section{Effect of time}

The removal capacity of physical and chemical variables on the reaction time is illustrated in Fig. 8. The experimental results of the chemical and following treatment explained those $12 \mathrm{~h}$ were not enough to find maximum removal capacity for any pollutants, but after one day the removal capacities for all factors executed maximum and they remained constant after treatment period two or more day's (Fig. 8). The experimental results indicated that the time of coagulation reaction and following settling has a large effect on the removal capacity for different factors. Thus the study suggested that $24 \mathrm{~h}$ reaction time would be sufficient to accomplish the hydrolysis and sedimentation processes for the coagulant.

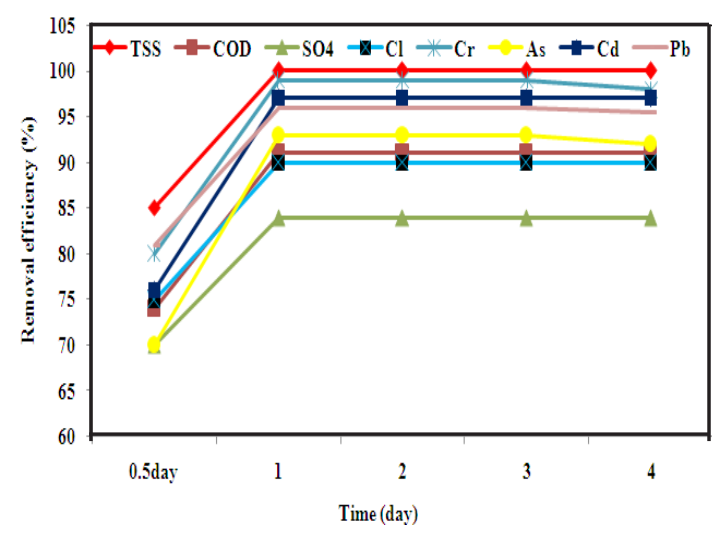

Fig. 8. The removal efficiency of some physical and chemical variables (TSS, COD, $\mathrm{SO}_{4}{ }^{2-}, \mathrm{Cl}^{-}, \mathrm{Cr}, \mathrm{As}, \mathrm{Cd}$ and $\mathrm{Pd}$ ) on reaction time for coagulant $\mathrm{Fe}_{2} \mathrm{O}_{3}$

\section{CONCLUSION}

The leather industries in Bangladesh are considered as one of the most serious pollutants industries in terms of both environmental concern and toxic parameters. The study found that tannery wastewaters contained exceptionally high values of TDS, TSS, TS, BOD, COD, $\mathrm{SO}_{4}{ }^{2-}, \mathrm{Cl}^{-}$and different heavy metals. The experimental results indicated that the theses physico-chemical parameters of the collected wastewater were exceeded the standard discharge limits. These tanning industrial wastewaters are very much harmful and toxic to surface water which poses potential threads to water ecosystem as well as human health. The study elucidated that the filtration processes could reduce certain amount of toxicants load from the industrial wastewater and its need further chemical treatment to discharge the effluents into river by maintaining standard permissible discharge limits. According to removal efficiency of toxicants load at optimum $\mathrm{pH} 9$, it executed that chemical treatment with $100 \mathrm{mg} / \mathrm{L}$ coagulant $\left(\mathrm{Fe}_{2} \mathrm{O}_{3}\right)$ does indicated the best results of the physical and chemical parameters which were much below the standard tannery wastewater discharged limits. In order to reduce the toxicants load from tannery wastewater, the study suggested that both combined physical (Filtration) and chemical (coagulation $\left(\mathrm{Fe}_{2} \mathrm{O}_{3}\right)$ treatment processes could be fruitful.

\section{ACKNOWLEDGEMENT}

The authors wish to acknowledge the 
Centre of Advanced Research in Sciences (CARS), University of Dhaka; Central Science Laboratory and the physical Chemistry laboratory, Department of Chemistry, Rajshahi University, Bangladesh for providing the technical facilities to carry out the experiments.

\section{Conflict of Interest}

Authors declare that they have no conflict of interest.

\section{REFERENCES}

1. S. Sungur and A. Özkan, "Characterization of Wastewaters Obtained from Hatay Tanneries," Nat. Eng. Sci., 2017, 2(2), 111-118.

2. B. O. Ejechi and O. O. Akpomie, "Removal of $\mathrm{Cr}$ (VI) from Tannery Effluent and Aqueous Solution by Sequential Treatment with Microfungi and Basidiomycete-Degraded Sawdust," J. Environ. Prot. (Irvine,. Calif)., 2016, 07(06), 771-777.

3. E. Leghouchi, E. Laib, and M. Guerbet, "Evaluation of chromium contamination in water, sediment and vegetation caused by the tannery of Jijel (Algeria): a case study," Environ. Monit. Assess., 2009, 153(1-4), 111-117.

4. M. Chowdhury, M. G. Mostafa, T. K. Biswas, and A. K. Saha, "Treatment of leather industrial effluents by filtration and coagulation processes," Water Resour. Ind., 2013, 3, 11-22, Sep. .

5. S. Kakkar, A. Malik, and S. Gupta, "Treatment of pulp and paper mill effluent using low cost adsorbents: An overview," J. Appl. Nat. Sci., 10(2), 695-704, 2018.

6. I. Au, M. E. Khan, D. P. Feka, and B. Ogoh, "Tannery Wastewater Evaluation and Remediation: Adsorption of Trivalent Chromium Using Commercial and Regenerated Adsorbents," J Water Technol Treat Methods., 2018, 1(1), 104, .
7. F. A. Batzias and D. K. Sidiras, "Dye adsorption by calcium chloride treated beech sawdust in batch and fixed-bed systems.," J. Hazard. Mater., 2004, 114(1-3), 167-74.

8. X. J. Jenitta, V. Daphne, V. Gnanasalomi, and J. J. Gnanadoss, "treatment of leather effluents and waste using fungi," 2013.

9. A. I. Zouboulis, P. A. Moussas, and F. Vasilakou, "Polyferric sulphate: Preparation, characterisation and application in coagulation experiments," J. Hazard. Mater., 2008, 155(3), 459-468.

10. Jia-Qian Jiang and Nigel J D Graham, "Pre-polymerised inorganic coagulants and phosphorus removal by coagulation - $A$ review., 1998, 24(3), 239-244.

11. O. S. Amuda, I. A. Amoo, and O. O. Ajayi, "Performance optimization of coagulant/ flocculant in the treatment of wastewater from a beverage industry.," J. Hazard. Mater., 2006 129(1-3), 69-72.

12. K.J.Manu, V.S. Mohana and G. K. Ganeshaiah, "Effluent Generation by the Dairy Units: Characterization and Amelioration for Irrigation,' Int. J. Res. Chem. Environ., 2011, 1, 173-182.

13. T. Mandal, D. Dasgupta, S. Mandal, and S. Datta, "Treatment of leather industry wastewater by aerobic biological and Fenton oxidation process.," J. Hazard. Mater., 2010 180(1-3), 204-11. 